\title{
Uitgangspunte en temas in Godsdienssosiologie
}

\author{
CS Steenekamp
}

\section{INLEIDING}

As ' $n$ reël werk sosiologie met min of meer konkrete, waarneembare objektief-kontroleerbare gegewenhede. Gepaard hiermee het godsdienssosiologie egter ook te doen met 'n transendente dimensie "agter" waarneembare verskynsels wat bestudeer word.

Vir godsdienssosiologie het godsdiens nie slegs op 'n transendente realiteit betrekking nie. Volgens Dekker is godsdiens ook 'n sosiale werklikheid. Dit neem die vorm aan waarin dit herken word in groepe en in groepverskynsels:

"Het komt erop neer dat God in en door mensen werkt, dat die goddelijke zijn neerslag vind in het menselijke. Dat, wat ook de bron, de oorsprong van bepaalde gebeurtenissen en verschijnselen mag zijn, zij voorzover wij er meer geconfronteerd worden, plaatsvinden in de menselijke samenleving"1.

Die opmerking dat "die goddelike neerslag vind in die menslike", dien terselfdertyd tot afbakening van die terrein van die godsdienssosiologie. Godsdienssosiologie kan beskryf word as die wetenskap wat hom besig hou met die studie van die verhouding tussen die mens en samelewing aan die een kant en die goddelike aan die ander kant $^{2}$. Met ander woorde, godsdienssosiologie bestudeer groepe en groepsverskynsels, groepskenmerke, en aspekte van menslike gedrag wat direk of indirek bepaal word deur die fenomeen godsdiens en die belewenis daarvan. Dit bestudeer godsdienstige groepe en groepsverskynsels onder spesifieke gesigspunte van hulle struktuur, funksies en veranderinge wat daarin voorkom. Godsdienssosiologie is dus 'n outonome, positiewe en empiriese wetenskap wat streef na ' $n$ algemene verklarende kennis van (a) die strukture, funksies en veranderinge van godsdienstige groepe en groepsverskynsels, (b) hul eksterne en interne samehang en teenstellings, en (c) hulle samehang en teenstellings met profane groepe en groepsverskynsels ${ }^{3}$.

Waar godsdienssosiologie te doen kry met geloof en gelowe wat as kosbaar en onaantasbaar beskou word deur mense, en met aspekte van mense se lewens wat vir hulle uiters belangrik is, behels godsdienssosiologie dus die ondersoek van die idees, houdings en geloof 
waardeur mense sin en betekenis verkry in hulle samelewing en van die wêreld soos hulle dit ervaar".

\section{GODSDIENSSOSIOLOGIESE AFBAKENING VAN GODSDIENS}

Die afbakening van die begrip godsdiens lê dus ten grondslag van enige godsdienssosiologiese ondersoek; dit bepaal trouens die metodologiese benadering wat gevolg word. Verskeie uitgangspunte met betrekking tot die onderwerp van godsdiens word aangetref, soos weerspieël in die benaminge "supernaturele, uiteindelike, heilige, ander-wêreldlike, transendente, goddelike, God," ens. of slegs "religieuse fenomene". Dikwels is van hierdie benaminge sinonieme, soms dui dit op verskillende konsepsies van die fenomeen.

Waardenburg stel dit dat die ondersoeker moet probeer om die eksistensiële probleme en die transendente referensies "agter" die spesifieke uitdrukkings wat hy bestudeer, te rekonstrueer. Die geslaagheid van die poging tot begrip of verstaan, hang af van die vermoë om die religieuse omstandighede waarop die uitdrukkings betrekking het, te konstitueer.

Die implikasie hiervan is dat godsdienssosiologie kan aanvaar dat besondere groepe (kerke) en samelewings (kulture) eiesoortige en unieke geloofsisteme en godsdienstige handelinge kan onderskryf.

Die definisie van godsdiens as 'n institusionele aspek van die samelewing wat gebaseer is op geloof in ' $n$ bo-menslike of supernaturele sfeer, druis nie in teen die erkenning van die transendente as 'n realiteit nie $^{6}$. Dit moet dus gestel word dat sosiologie die teologiese definisies eerbiedig wat 'n samelewing of groep met betrekking tot die openbaringskarakter van sekere begrippe, spesifiek God, handhaaf.

Dit is ' $n$ wanopvatting dat godsdienssosiologie die realiteit van die heilige (die "sacred" én die "holy"), die transendente, of die uiteindelike, ontken ${ }^{7}$. Godsdienssosiologie kan godsdiens beskou as die geloof in en verhouding tot waardes van transendentale betekenis, die laaste mag of magte wat verantwoordelik geag word vir die geheel of belangrike deel van die fundamentele wêreldorde en van die menslike bestaan". (Hierdie uitgangspunt is nie algemeen in godsdienssosiologie nie; daar is godsdienssosioloë wat ontken dat met die transendente as sosiologiese veranderlike rekening gehou behoort te word.)

So 'n uitgangspunt, waar die klem op die eiesoortigheid van geloofs- en rituele sisteme gelê word, is fundamenteel hermeneuties: dit wil die lewe van mense verstaan soos hulle dit self ervaar; dit het ten doel om die betekenis te probeer begryp wat aan verskillende 
situasies geheg word in terme van die komponente van die onderskeie mense se geestelike wêrelde; dit het, met ander woorde, te doen met interpretasie.

\section{TERREIN VAN GODSDIENSSOSIOLOGIE}

Oor die afbakening van die terrein van godsdienssosiologie, en gevolglik 'n metodologie, is daar nie eenstemmigheid nie. Sosioloë wat die twee verskillende perspektiewe ten opsigte van godsdienssosiologiese metodologie huldig, is daarmee eens, en stel dit pertinent, dat daar groot verwarring heers oor die aard, omvang en metodes van godsdienssosiologie:

"Unfortunately there are still important disagreements concerning the definition of sociology of religion"9.

Enersyds is daar wat genoem word "kerk-sosiologie" of "godsdienstige sosiologie", en andersyds is daar godsdienssosiologiese rigting wat die teoretiese relevansie van godsdiens as universele fenomeen bestudeer. Hierdie tweeledige karakter is deels verantwoordelik vir 'n sogenaamde dilemma waarin godsdienssosiologie verkeer: "Being a science which relates to man, on the one hand, and to sacred matters, on the other, it was threatened from both sides"10. Volgens Budd kon die kerklik-georiënteerde benadering weinig bydra om lig te werp op die breër probleem van die rol van godsdiens in die samelewing; die voordeel daarvan was egter dat godsdienssosiologie, as gevolg van die empiriese navorsingsmetodes wat aangewend is, hom kon vrywaar teen onkontroleerbare spekulasie en veralgemenings ${ }^{11}$. Volgens Berger en Luckmann is die belangstelling van kerklik-georiënteerde godsdienssosiologie beperk tot kerk-geaffilieerde godsdiens en die afwesigheid of aanwesigheid daarvan sou dui op 'n "goeie" of "slegte" toestand van sake; "Needless to say, research carried on under ecclesiastical auspices shares the problem with the activities of sociologists employed by other types of bureaucratic management ${ }^{\prime 212}$. Sodanige godsdienssosiologie is byvoorbeeld die van Le Bras vir wie godsdienstige deelname slegs 'n maatstaf was om religieuse vitaliteit van groepe, kollektiwiteite of kategorieë vas te stel.

Met verloop van tyd het die klem verander in godsdienssosiologiese navorsing, en al meer gerig geraak op 'n veld van dinamiese strukture wat in verhouding met ander gedragspatrone staan. Kerksosiologie meet die individuele deelname aan die strukture, en nie die dinamiese verhouding tussen strukture onderling nie. In tye van sosiale verandering is juis laasgenoemde belangrik. Dit was veral met betrekking tot die verval van sommige kerke en godsdienstig- 
geagte patrone dat die klem begin val het op strukturele probleme rondom kerk en godsdiens. Die godsdienssosioloog het hom dus in groter mate begin afvra in welke mate kerk en godsdiens marginaal gemaak word deur veranderde maatskaplike strukture ${ }^{13}$.

Gill verwys ook na die dichotomie tussen godsdienssosiologie ("sociology of religion") en godsdienstige sosiologie ("religious sociology") en meld dat lg nie veel waardering in sosiologie geniet nie; dit word geargumenteer dat die sosioloog 'n neutrale houding ten opsigte van die geloof, praktyk en ervaringe van die samelewing wat hy ondersoek, moet inneem. Hy is nie veronderstel om met die geldigheid van 'n godsdiens te doen te hê nie. Of daar 'n God is of nie, of Christus die Seun van God is of nie, is nie aangeleenthede waaroor 'n wetenskap kan besluit nie, of waarmee dit iets te doen hoef te hê nie. Sosiologie moet dus, volgens Gill, neutraal bly teenoor transendente ${ }^{14}$.

Anders as Berger en Luckmann verdedig Gill egter die "religious sociology" juis op grond daarvan dat daar bloedweinig dissiplines binne sosiologie is wat slegs daarop uit is om suiwer kennis in te samel. Daar is byvoorbeeld weinig kritiek teen industriële sosiologie, en dergelike, waarin soms juis 'n beroep op die sosioloog gedoen word om ' $n$ bepaalde doel te dien. Waarom, vra Gill, kan sodanige uitsonderings (sosiologie van die opvoeding en rasse-sosiologie word ook genoem) geduld word, en nie die van godsdienssosiologie nie? ${ }^{15}$

Gill se argument is slegs gedeeltelik geldig: waarmee hy nie rekening hou nie, is dat toenemende getalle individue in geindustrialiseerde samelewings nie meer formeel ritueel-verbonde by religieuse instellings betrokke is nie. Uit die aard van die saak sal die terrein van die godsdienssosiologie uitkring om voorsiening te maak vir' $n$ nuwe situasie:

"Hij gaat onderzoeken welke nieuwe legitimatiepatronene zich op verschillende niveaus aan het ontwikkelen zijn en welke rol daarbij aan de kerk noch toegewezen wordt. Kortom, de socioloog moet zich niet afvragen wat de relevantie is van kerk en godsdienst voor het individu, maar wèl wat hun maatskappelijk relevantie is" ${ }^{\prime \prime}$.

In hierdie sin het die godsdienssosiologiese belangstellingsveld van deelname (participatie) na sekularisasie verskuif. Gevolglik is godsdienssosiologie objektief en abstrak, bestudeer dit empiriese fenomene in ' $n$ poging om veralgemenings te identifiseer met betrekking tot die wisselwerking van religieuse gedrag en ander samelewingsgedrag ${ }^{17}$.

Die vraag oor die aard van die verhouding godsdiens en samele- 
wing, in 'n situasie waarin die tradisionele aannames oor geloof gedelegitimeer is, kan volgens Gannon slegs beantwoord word indien duidelikheid heers oor vrae soos:

- Op welke wyse en onder watter omstandighede affekteer die godsdienstige en sosiale sisteme mekaar?

- In watter mate is die geloof, waardes en normatiewe strukture van 'n gegewe godsdienstige sisteem onderling afhanklik?

- Deur welke prosesse en sosiale meganismes word hierdie elemente van oorgelewerde religieuse sisteme gewysig en aangepas in toestande van snelle veranderinge en pluralisme ${ }^{18}$

\section{INTERPRETASIE VAN DIE RELIGIEUSE FENOMEEN}

Waardenburg sê dit bly 'n vraag of daar iets "agter" 'n individu en sy religieuse uitdrukking, byvoorbeeld gebed, of ' $n$ religieuse fenomeen, byvoorbeeld ' $n$ standbeeld, is. Dit kan selfs vir die betrokke persoon ' $n$ raaisel wees. Uit ' $n$ fenomenologiese standpunt moet toegegee word dat die gebed, en die beeld, betekenis het: ' $n$ betekenis waartoe die ondersoeker "toegang" kan hê op grond van die waarde wat die individu of groep aan die gebed of beeld heg: die fenomenologiese navorser soek na intensies, "he tries 'to understand religious meaning ${ }^{\prime \prime 19}$.

Drijvers wys daarop dat dit 'n "mode" was in die fenomelogiese benadering in die godsdienssosiologie, waar dit veral gegaan het om vergelykings, om tevrede te wees met die "verstehen" van religieuse strukture ${ }^{20}$.

Daar moet egter ' $n$ empiriese vertrekpunt in 'n godsdienssosiologiese ondersoek wees - op een of ander wyse moet godsdiens gedefinieer kan word. Deur daarvan bewus te wees dat nòg die intensie, nòg die objek van die intensie geredelik vir die navorser beskikbaar is, word aanvaar dat dit "aangedui" kan word deur feite wat toeganklik is.

Gevolglik wil dit voorkom ásof die argument van onder andere Bowker, naamlik dat dit redelik sinloos lyk om betekenisse aan religieuse simbole toe te skryf wat nouliks deur 'n ondersoekgroep herken of erken sal word, as geldig voorkom ${ }^{21}$. Dit kom daarop neer dat wanneer die godsdienssosiologie hom besig hou met die interaksie tussen godsdiens en samelewing, "moet duidelik besef word dat die sosioloog nie wil uitspraak doen oor die wese, ontstaan en teologiese betekenis van die godsdiens nie ${ }^{\prime 22}$. Anders as onder andere Kehrer wat die standpunt huldig dat daar geen verbode terrein vir die godsdienssosioloog bestaan nie ${ }^{23}$, kan godsdienssosiologie die gesag van die Skrif erken. Hierdie aanname beteken egter nie dat geen uitsprake oor die onderlinge religieuse en sosiale verhoudinge 
van die ondersoekgroep, of oor die verhouding van mens tot God, of oor die mens se interpretasie van die Openbaring en die relevansie daarvan vir die mens, gemaak sal word nie. Met ander woorde, oor die manifestasie van religie in die samelewing word krities besin ${ }^{24}$.

\section{OBJEKTIWITEIT IN GODSDIENSSOSIOLOGIE}

Die feit dat godsdienssosiologie nie ' $n$ normatiewe wetenskap is nie, mag nie tot misverstand lei nie: die godsdienssosioloog interesseer hom deeglik in die wetboeke, reëls, konstitusies, gebruike, ens. as feitelike gegewenhede wat medebepalend is vir die gedrag van godsdienstige groepe, en as deel van hul groepskultuur.

Kennis van hierdie norme, waardes en verwagtinge is onmisbaar vir die juiste begrip en juiste aanduidings van die sosiale struktuur en funksies van godsdiens. Die aanname kan gemaak word dat die persoonlike of subjektiewe oortuigings van die ondersoeker nie ' $n$ rol behoort te speel in die evaluering van gegewens nie: hy moet in staat wees om die uitsprake van die ondersoekgroep oor alle aangeleenthede onbevooroordeeld te evalueer. Die standpunt stem ooreen met die van Dekker wat daarop gewys het dat die sosioloog as wetenskaplike die waardes wat hy onderrsoek, nòg ontken, nòg bevestig, net eenvoudig omdat dit in 'n wetenskaplike ondersoek nie relevant is nie. Objektiwiteit beteken nie onverskilligheid nie, dit beteken dat "men zijn eigen waardeoordelen niet mee laat spreken in de resultaten van zijn werkzaamheden" ${ }^{25}$.

\section{Verwysings}

1. Dekker, G. Sociologie en kerk: over het recht en het nut van de sociologie met betrekking tot de kerk. Kampen: Kok; 1969: 25. Dekker is slegs een van verskeie godsdienssosioloë wat hierdie uitgangspunt onderskryf.

2. Vrijhoff, $\mathbf{P H}$. What is the sociology of religion? in Brothers, Joan. Readings in the sociology. Oxford: Pergaman, 1967.

3. Goddijn, W en Goddijn, HPM. Godsdienssociologie: het groepsleven van de Christenen. Utrecht: Spectrum; 1960: 30.

4. Towler, Robert. Homo religiosus: sociological problems in the study of religion. London: Constable; 1974: 1.

5. Waardenburg, JDJ. Research on meaning in religion, in Van Baaren, Th $\&$ P Drijers. Religion, culture and methodology. The Hague: Mouton; 1973: 125.

6. Birnbaum, N. 1964: Religion, in Gould, J. \& Kolb, WL Dictionary of the social sciences. London: Tavistock; 1964: 589.

7. Schneider, L. Religion, culture and society. New York: Wiley; 1964: 26.

8. Goddijn, W \& Goddijn, HPM, op cit p 10. Onder ander godsdienssosioloë wat eksplisiet die transendente karakter van godsdiens onderskryf, tel oa Betty Betty $R$ Scharf. (The sociological study of religion. London: Hutchinson; 1974.)

9. Yinger, J Milton. Sociology looks at religion. New York: Macmillan; 1966: 165. Yinger kan beskou word as 'n eksponent van 'n universele godsdienssosiologie. Dieselfde sienswyse word gedeel deur G le Bras, algemeen bekend as die grond- 
legger van kerk-sosiologie. (Religious sociology and sciences of religions, in Brothers, Joan. Readings in the sociology of religion. Oxford: Pergamon; 1967: 133).

10. Poulat, E Religious sociology and its aims, in Brothers, Joan. Readings in the sociology of religion. Oxford: Pergamon; 1967: 151.

11. Budd, Susan. 1973: Sociologists and religion. London: Collier-Macmillan; 1973: 3.

12. Berger, Peter, L \& Luckmann, T. Sociology of religion and sociology of knowledge. Sociology and Social Research, vol 47, 1963: 417-427.

13. Dobbelaere, Karel \& L Layendecker. Godsdienst, kerk en samenleving: godsdienstsociologische opstellen. Rotterdam: Universitaire Pers; 1974: 119.

14. Gill, Robin. The social context of theology. London: Mowbrays; 1975: 15.

15. Ibid. $\mathrm{p} 24$.

16. Dobbelaere \& Layendecker, op cit p 120.

17. Yinger, op cit $\mathrm{p} 155$.

18. Gannon, Thomas, $M$. In the eye of the hurricane: religious implications of contemporary trends. Social Compass, Vol 19, 1972: 219.

19. Waardenburg, JDJ. Research on meaning in religion, in Van Baaren, Th $P$ \& Drijvers. Religion, culture and methodology. The Hague: Mouton, 1973: 121-123.

20. Drijvers, HJW. Theory formation in science of religion and the study of the history of religions, in Van Baaren, Th, P \& Drijvers, HJW. Religion, culture and methodology. The Hague: Mouton, 1973: 64.

21. Bowker, John. The sense of God: sociological, anthropological and psychological approaches to the origin of the sense of God. London: Clarendon; 1973: 181.

22. Alant, CJ. ' $n$ Sosiologiese studie van die beeld wat die gemeentelid in die Nederduitse Gereformeerde Kerk van die predikant het. Pretoria: NG Kerkboekhandel: 1969: 1 .

23. Kehrer, Günter. Religionssoziologie. Berlin: Walter de Gruyter (Sammlung Göschen); 1968: 15.

24. Goddijn \& Goddijn, op cit p 16.

25. Dekker, op cit p 32-33. 